\title{
Legal Political Analysis of Failure Factors of Extradition Treaty Ratification between Indonesia and Singapore
}

\author{
Dio Poliando Panggabean ${ }^{1}$, Suhaidi $^{2}$, Ediwarman $^{3}$, Jelly Leviza ${ }^{4}$ \\ \{dio.panggabean35@gmail.com ${ }^{1}$, suhaidi@usu.ac.id ${ }^{2}$, profediwarman25@yahoo.com ${ }^{3}$ \\ jelly@usu.ac.id $\left.{ }^{4}\right\}$
}

Universitas Sumatera Utara, Indonesia ${ }^{1,2,3,4}$

\begin{abstract}
Indonesia has been exploring an extradition treaty with Singapore since 1970's but still fails to ratify the extradition treaty due to the mismatch between the conditions proposed by the Singaporean Government. This normative legal research to reveal the main causes of the extradition treaty ratification failure. After a long negotiation process, Indonesia and Singapore agreed on an extradition treaty followed by a defense cooperation agreement (DCA). Several legal factors have caused the failure to follow up the extradition treaty including the integration of the extradition agreement package with the DCA and the clause that Singapore has the right to conduct military training by involving third parties in Indonesian territory. Moreover, Singapore adheres to the Common Law legal system that stipulates extradition through courts. Furthermore, some political factors have contributed to the failure of the extradition treaty including the absence of a guarantee from the Singaporean government that fugitives and their assets can be brought to be processed by Indonesian law. Domestic legal politics and international relations greatly influence the decisions to ratify the extradition treaty indicating that there is a certain motive behind the insertion of the defense cooperation agreement into the extradition treaty.
\end{abstract}

Keywords: Analysis, Ratification, Extradition, Singapore

\section{Introduction}

Extradition is the product of rational exchanges between 2 or more countries. One of the fundamental aspects relating to extradition requests can only be carried out by the order of the executive. This means that the extradition decision is fully sovereign in the hands of the president as the head of state. There is an opinion claiming that the extradition request is based more on the political interests of the president than on the law itself [1].

The massive cases of international crimes have caused the perpetrators to flee abroad. Therefore, in the context of handling and anticipating criminal acts, an instrument in the form of international cooperation for law enforcement is needed to carry out legal processes in both the requesting country and the requested country. This should be manifested in an extradition treaty.

The government has been working hard to explore extradition treaties since the 1970s with several neighboring countries such as the Philippines, Malaysia, Thailand, Australia, Hong Kong, South Korea, and Singapore. Almost all of these countries have accepted the Indonesian government's invitation, except the Singaporean government that has not responded due to the differences in the legal system between the two countries. 
These differences have made the Indonesian Government experience obstacles in realizing the ratification of the extradition treaty with Singapore. In practice, the Singaporean court can cancel the requests to bring corruptors out of its country due to court decisions. In the Continental system, legislation or codification is used as the main law. Meanwhile, in the Anglo-Saxon system, precedent (previous court decisions) and customs are the main sources of law. The Anglo-Saxon system places the court as the party determining whether a person can or cannot be extradited.

A common law system requires that extradition processes must go through a trial stage which cannot be resolved through a single court level. In Indonesia, on the other hand, the extradition process generally does not take a long time because it is part of the executive power, not the judiciary as in common law countries. Thus, an extradition process can be carried out in a relatively short time.

Despite the differences in the legal system between the two countries and less smooth negotiation, the process of negotiation does not stop. Indonesia and Singapore have once collaborated in the defense sector called the Air Combat Maneuvering Range (Air Combat Training Ground) in Pekanbaru which was built by Singapore to be used together with Indonesia. The two countries are close to each other and have good diplomatic relations. However, both of the countries have not ratified the extradition treaty. This is despite the fact that the extradition treaty process with Singapore has been started since 1974. The long process is due to the complicated extradition treaty issue related to bilateral issues which are quite complicated and a tug of war between political and legal interests between the two countries.

The Indonesian and Singaporean governments signed a memorandum of understanding on extradition done by the respective Foreign Ministers witnessed by Indonesian President Susilo Bambang Yudhoyono and Singaporean Prime Minister Lee Hsien Loong on 27 April 2007 at the Tampaksiring Palace, Bali. Considering the contents of the agreement are related to politics, security, and sovereignty or sovereign rights of the country, the ratification is then carried out by law.

The constraint and obstacle to the failure of ratifying the extradition treaty are the conditions proposed by the Singaporean Government which are deemed incompatible with the main substance of the agreement. Insertion of the Defense Corporate Agreement (DCA) into the extradition treaty by Singapore by asking an area in Indonesia to be used as a military training ground is considered inappropriate. The Indonesian government refused it following the decision of the House of Representatives. Singapore's request is unusual. The government has made many extradition treaties with various countries without such a request in the agreement.

There are allegations that the Singaporean government deliberately did not follow up on the extradition treaty to protect Indonesian fugitives. They were involved in such various problems as crimes or corruption, smuggling, reclamation, and several other problems. Therefore, Singapore has received reprimands from various domestic and international entities such as NonGovernment Organizations (NGOs) and international organizations that consider Singapore to be uncooperative in handling corruption. The evidence leading to these allegations is that most of the Bank Indonesia Liquidity Assistance (BILA) recipients who caused a loss of hundreds of trillions of rupiah in state finances are believed to be in Singapore, and they are not processed according to the local laws. This research analyzes legal political factors on the failure of extradition treaty ratification between the Indonesian and Singaporean governments. 


\section{Research Method}

This is normative legal research which is also called doctrinal legal research. The law is often conceptualized as what is written in legislation (law in the book) or law that is conceptualized as rules or norms which become standard behavior guidelines for people that are considered appropriate relating to extradition. In addition, this study uses a descriptive method by providing the data regarding the symptom or phenomenon as accurately as possible, in this context, the inhibiting phenomena causing the failure to ratify the extradition treaty between Indonesia and Singapore.

\section{Results and Discussion}

\subsection{Brief History of the Extradition Treaty between Indonesia and Singapore}

The long history of the absence of a bilateral agreement (extradition) between Indonesia and Singapore is thought to be motivated by the conflict of political and economic interests between the two countries. Indonesia has an interest in promoting the rule of law (e.g., corruption eradication), while Singapore has an interest in maintaining its reputation as one of the economic centers in ASEAN. Therefore, dirty money (money from corrupt practices in Indonesia) can easily come and go via Singapore [2].

The extradition treaty between Indonesia and Singapore is difficult to implement. Singapore has shown a change in attitude since the end of 2004. During the bilateral meeting attended by the prime minister of the Republic of Singapore and the president of the Republic of Indonesia in Tampaksiring, Bali, on 4 October 2005, a mutual understanding emerged that the negotiation process for the extradition treaty and the new cooperation agreement in a defense sector would be carried out parallelly.

The parallelization is carried out in the political field, including three agreement negotiations: defense agreement, extradition treaty, and counter-terrorism agreement. This indicates a good relationship but raises pros and cons from various elements of society because the agreement involves the political and defense sectors.

The meeting held in Langkawi on 14-15 May 2007 was effective. Two weeks before the Summit Conference, Indonesia and Singapore have concluded the Extradition Treaty and Defense Cooperation Agreement (DCA). After going through a fairly long and dynamic negotiation process for more than 30 years, on 27 April 2007 in Tampaksiring, Bali, Indonesia and Singapore agreed on a defense cooperation agreement. The agreement was signed in a package with an extradition treaty.

The signing of the agreement triggers pros and cons which makes Indonesia and Singapore caught in a very serious dilemma. The criticism of the agreement is regarding several areas agreed to be used as the military training ground. Some international legal experts argue that determining Indonesian territory as a joint military training ground is a violation of the territorial law sovereignty of the Republic of Indonesia.

Here's the characteristic of extradition treaty between Indonesia and Singapore [3]:

a. Transfer of case or right of prosecution in the event that the state is asked not to surrender its citizens whose extradition is requested by the requesting country. 
b. For an extradition respondent who is detained based on a request for temporary detention, there is no time limit for detention until the formal request for extradition must have been received by both parties through diplomatic channels.

c. Criminal penalty of at least two years against extraditable criminals.

d. The treaty is retroactive 15 years after the treaty enters into force against all extraditable crimes.

e. The application of the prima facie principle or sufficient evidence of the alleged crime if the crime occurred in the jurisdiction of the requested party.

f. It does not clearly regulate whether or not a respondent of extradition who is threatened or sentenced to death can be extradited.

g. The types of crimes for which the perpetrators can be extradited are regulated in the list of crimes as many as 29 types of crimes and other criminal acts that can be extradited according to the extradition laws of both parties and the laws that ratify obligations under international conventions to which both parties are parties.

h. The extradition respondent who is detained but the requested state still requires additional information and the additional information is not received by the requested state within the specified time, the person can be released. The release does not prevent the requesting country from submitting a new extradition request for the person.

The extradition treaty between Indonesia and Singapore is actually the first step in following up the ratification of the extradition treaty that has been signed. Basically, DCA is the body that defines the terms and conditions of implementing the Military Training Area (MTA) and Implementation Agreement (IA). Therefore, it needs to be further elaborated [4].

Defense cooperation between Indonesia and Singapore is one of the forms of Indonesian diplomacy in establishing bilateral cooperation with Singapore. The extradition treaty is the first step in improving the relationship between Indonesia and Singapore. Previously, Singapore only entered into extradition treaties with British Commonwealth countries and only interacted with certain countries. Indonesia and Singapore formed a joint technical meeting that specifically discussed the follow-up to the extradition treaty. In the end, the political interests between the two countries played a major role in following up the extradition treaty [5].

An ongoing extradition treaty cannot practically override global cooperation with institutional channels. The role of INTERPOL as an international organization accommodating the national police of its member countries is still needed because of its important role in preventing, eradicating, and pursuing perpetrators of both national and international crimes. At the regional level, for example, cooperation involves the police institutions of ASEAN member countries [6].

There are some several cases of extradition dispute between Indonesia and Singapore [7]:

\begin{tabular}{|c|c|c|c|}
\hline No. & Fugitive & Case & $\begin{array}{l}\text { Court Decision } \\
\end{array}$ \\
\hline \multirow[t]{7}{*}{1} & \multirow{7}{*}{$\begin{array}{l}\text { Sudjino Timan } \\
\text { Last seen: } \\
\text { Resided in Ardmare } \\
\text { Park Singapore }\end{array}$} & \multirow{7}{*}{$\begin{array}{l}\text { Corruption in PT Bahana } \\
\text { Pembinaan Usaha Indonesia } \\
\text { causing total state loss in 1995- } \\
1997 \text { amount of Rp. } 369 \text { billion } \\
\text { and US\$ } 178 \text { million }\end{array}$} & Supreme $\quad$ Court \\
\hline & & & $434 / \mathrm{K} / \mathrm{Pid} / 2003$ on 2 \\
\hline & & & December 2004 sentenced \\
\hline & & & 15 years in prison, fined $\mathrm{Rp}$ \\
\hline & & & 50 million, substitute \\
\hline & & & compensation \\
\hline & & & billion and US\$98 million \\
\hline \multirow[t]{4}{*}{2} & \multirow[t]{2}{*}{ Samadikun Hartono } & \multirow{4}{*}{$\begin{array}{l}\text { Corruption using liquidity aid } \\
\text { from Indonesia Central Bank } \\
\text { causing total state loss Rp. } 169 \\
\text { billion in 1997-1998 }\end{array}$} & $\begin{array}{lll}\text { Supreme } & \text { Court } & \text { No. }\end{array}$ \\
\hline & & & $1696 / \mathrm{K} / \mathrm{Pid} / 2002$ date 28 \\
\hline & \multirow[t]{2}{*}{ Last info: } & & May2003 sentenced 4 years \\
\hline & & & in prison, fine $\mathrm{Rp} 20$ \\
\hline
\end{tabular}




\begin{tabular}{|c|c|c|c|}
\hline & $\begin{array}{l}\text { Resided in apartment } \\
\text { Beverly Hills } \\
\text { Singapore and Had } \\
\text { Fuji Film Factories in } \\
\text { China and Vietnam }\end{array}$ & & $\begin{array}{ll}\text { million, } & \text { susbstitute } \\
\text { compensation } & \text { Rp. } 169 \\
\text { billion and US\$ } 98 \text { million }\end{array}$ \\
\hline 3 & $\begin{array}{l}\text { Bambang Sutrisno } \\
\text { Last info: } \\
\text { Resided in } 721 \text { Bukit } \\
\text { Timah Road } \\
\text { Singapore } 269768\end{array}$ & $\begin{array}{l}\text { Corruption in Bank Surya } \\
\text { together with Adrian Kiki } \\
\text { Irawan causing total state loss } \\
\text { Rp. } 1,51 \text { trillion in 1989-1997 }\end{array}$ & $\begin{array}{l}\text { High Court Jakarta No. } \\
\text { 71/Pid/2003/PT DKI date } 2 \\
\text { June } 2003 \text { sentenced for } \\
\text { a life time, fine Rp. } 30 \\
\text { million, } \\
\text { compensation Rubstitute } \\
\text { trillion via in absentia trial }\end{array}$ \\
\hline
\end{tabular}

The absence of ratification extradition treaty has made it difficult for Indonesia through its law enforcement apparatus to bring back the perpetrators of corruption cases to trial. Through the extradition treaty, the government can easily handle to coordinate with the law enforcers, both Indonesia and Singapore, and the jurisdiction will be broader in tracking and pursuing suspects, especially suspects in corruption cases to repatriate corrupt assets that cause state loss around 1.300 trillion rupiah.

\subsection{Factors Affecting the Failure of the Extradition Treaty Ratification between Indonesia and Singapore}

Indonesia and Singapore are still not bound by an extradition treaty. In resolving the extradition case, the two countries are guided by legal principles and rules regarding extradition that have been generally adopted by countries throughout the world. An extradition institution has been recognized and accepted by international criminal law scholars as international customary law [8].

International law explicitly states that a country has the right to grant or refuse a request for submission of a criminal who is hiding in its territory if there is no previous extradition treaty. Due to the absence of an extradition treaty, a country can make extradition based on good relations and the need of its legal or political interests, although theoretically, an extradition treaty is an absolute requirement.

The extradition treaty between Indonesia and Singapore is an agreement that the Indonesian government has been pursuing for a long time. After Indonesia signed the anti-corruption convention (United Nations Convention Against Corruption 2003) and ratified it, Indonesia has shown the international community its high commitment and seriousness in preventing and eradicating corruption. This is in line with the government's objective to ratify the extradition treaty, i.e., to repatriate the corruptors.

Indonesian corruptors who fled to Singapore took advantage of the absence of an extradition treaty. They know that Indonesia has not been able to implement the extradition treaty with Singapore because it has not yet been ratified. Even though the government is aware of the existence of these corruptors, Indonesia is still hit by the absence of extradition ratification.

The absence of extradition treaty ratification can be overcome by using Mutual Legal Assistance and covert extradition which are guided by the principle of reciprocity between the two countries. Returning corruption without repatriating assets is futile because it must be done through formal legal procedures and based on the treaty ratification by both countries. 
The failure to ratify the extradition treaty between Indonesia and Singapore is caused by difficulties to accommodate the interests of each country. Therefore, the two countries often use multilateral cooperation platforms (especially ASEAN) as a forum to communicate and take advantage of Interpol's existence to handle transnational criminal cases. However, the effectiveness of this effort is not so significant, constrained by the problem of differences in their respective legal system and sovereignty.

Several legal factors are leading to the failure of following-up the extradition treaty in Indonesia [9]:

a. The integration of the Extradition Treaty with DCA is inappropriate because extradition and DCA are two different dimensions. The integrated extradition treaty package is inappropriate as if Indonesia sells its territorial sovereignty to Singapore as its military training ground to secure an extradition agreement to repatriate Indonesian money that has been brought to Singapore [10].

b. The Singaporean government said that there was no need to make an Implementing Arrangement because the contents of the agreement made in Tampaksiring, Bali, had already been comprehensive. Differences in interpreting the contents of the DCA are fatal in a bilateral agreement. An agreement cannot be ratified if it has a tendency of multiple interpretations on the provisions contained therein. Such a different interpretation can fail the ratification of the extradition treaty.

c. The Singapore government has the right to involve a third party in military training on Indonesian territory. This authority has exceeded the sovereignty of the Indonesian nation. In addition, the term of the Indonesian-Singaporean DCA is valid for 25 (twenty-five) years. In practice, such an agreement has never been done by Indonesia. The usual period in a bilateral agreement is 5 (five) years. The DCA agreement should only be carried out in a temporary period. This is intended to easily make changes that are more profitable for Indonesia.

d. An impractical extradition treaty can repatriate corrupt assets and money directly because it only regulates the repatriation of people. Singapore adheres to an Anglo-American legal system or known as a Common Law System. In this system, the party deciding whether someone is extradited is the court, not the government. The Indonesian government's request for repatriating corruptors (extradition) entirely depends on the Singaporean court decision. Therefore, the signed extradition treaty becomes difficult to implement when faced with the application of Singaporean law [11].

e. The principle of reciprocity states that the requesting country can repatriate a perpetrator if the request is replied to by the requested country. In this context, the extradition treaty can actually be implemented without ratification, but the Singaporean government will not follow this principle because it is detrimental to its position [12].

In addition to legal factors, political factors also contribute to the failure of following-up the extradition treaty in Indonesia, namely:

a. The transfer of fugitives and their assets from Singapore to Indonesia is still uncertain due to their movability. There is no guarantee from the Singaporean government that the fugitives and their assets can be taken for processing under Indonesian law. Thus, the Indonesian government's reason for agreeing with the DCA is that Singapore has agreed on an extradition treaty that is not in favor of Indonesia.

b. Some clauses are detrimental. In Article 6 of the Implementing Arrangement (IA), Singapore has the right to conduct joint military training with Indonesia in the areas called Alpha 1, Alpha 2, and Bravo areas; whereas these areas have strategic national defense facilities. The condition becomes much weirder when the Indonesia-Singapore DCA can only use 
Indonesian territory, and it is not possible for the Indonesian National Armed Forces to carry out military training in Singapore. The National Armed Forces are only allowed to use Singapore's military facilities [13]. This clause should refer to the principle of balance where the position of the two parties involved in the agreement is balanced and mutually beneficial so that it can accommodate the political interests of each country [14].

c. There are differences in views between the stakeholders. While the Indonesian government views the cooperation as beneficial, the House of Representatives considers that the ratification of the extradition treaty with the inclusion of DCA violates the territorial sovereignty of the Republic of Indonesia [15].

The Indonesian government thinks of the importance of fighting for the extradition treaty with Singapore considering the material losses caused by corruptors who have fled to Singapore. As a matter of fact, the extradition treaty should not include a DCA agreement. This political stance (making an extradition treaty with Singapore) is taken because if Singapore and Indonesia do not carry out the extradition, corruptors from Indonesia can flee to farther countries and it will become more difficult for Indonesia to trace the corruptors who carry out money laundering, especially in Singapore.

The postponement of extradition between Indonesia and Singapore is also related to the existence of political and legal interests between the two countries which are considered to be lame due to different perspectives and political interests. For Indonesia, extradition is one of the ways to repatriate state assets. Singapore, on the other hand, seeks to bring the realm of extradition cooperation to a broader level with the condition of inserting a defense cooperation agreement. Under this agreement, Singapore can take advantage of Indonesia's geographical area [16].

The amendment to the extradition treaty between Indonesia and Singapore is also one of the factors leading to the failure of the Indonesian government to agree on an extradition treaty with Singapore. One of the most important amendments to the extradition treaty is that it applies not only to corruption crimes but also to other crimes such as murder, narcotics, forest burning, and other serious crimes. In addition, the amendment made in this extradition treaty is that the arrests of criminals who have fled to Singapore are retroactive for 15 years since the extradition treaty was agreed. This is certainly not approved by Singapore.

The conflict of political and legal interests of each country is also an obstacle, especially in terms of exchanging information on the identity of the criminals. This problem will arise when the extradition treaty is implemented. The existence of cooperation in the military/defense sector inserted in the extradition treaty, as in the case between Indonesia and Singapore, is practically an inhibiting factor. In the context of DCA, Singapore wants military cooperation with Indonesia, while this is a threat to Indonesia's territorial sovereignty because the agreement will probably make Singapore indirectly control the Indonesian military power and territory [17].

Based on the factors and interests elaborated above, Indonesia can apply the international standard in eradicating corruption by utilizing the legal framework and so forth. In addition, Indonesia can urge the international community to eradicate corruption regarding issues related to the extradition efforts of corruptors through the application of Mutual Legal Assistance (MLA), asset recovery, and other legal institutions. 


\section{Conclusion}

The ratification of the extradition treaty between Indonesia and Singapore is influenced by the direction of domestic legal political policies. The direction of international relations that has not yet been determined greatly influences the decision on the following-up the extradition treaty. Indonesia is at a disadvantage position, so it is very reasonable to reject ratification because the position of the extradition treaty is not proportional. Therefore, the Indonesian government decided not to ratify the extradition treaty. From the elaboration of the legal and political factors above, the causes of the failure to ratify the extradition treaty between Indonesia and Singapore are political and legal considerations such as differences in the legal system and terms of the agreement which require defense cooperation that does not benefit Indonesia at all. The tug of war of interest indicates a certain motive behind the insertion of defense agreement into the extradition treaty.

\section{References}

[1] E. L. Simanjuntak, "Incoming Extradition in Indonesia and Its Implication to Human Rights," Walisongo Law Rev., vol. 1, no. 2, p. 113, 2020, doi: 10.21580/walrev.2019.2.2.5213.

[2] I. M. R. Mahayasa, "Perjanjian Ekstradisi Antara Indonesia dengan Singapura Sebagai Upaya Pengembalian Pelarian Koruptor Indonesia di Singapura," Univ. Brawijaya, p. 16, 2012.

[3] H. Adolf, "Badan Pembinaan Hukum Nasional," no. 45, pp. 1-113, 2009.

[4] F. Rani and R. Sanur, "Kebijakan pemerintah Indonesia meratifikasi perjanjian ekstradisi dengan Singapura tahun 2008-2012," J. Online Mhs., vol. 1, no. 1, pp. 1-14, 2014.

[5] Poerwadarminta, Ekstradisi dalam Hukum Internasional dan Hukum Nasional. Bandung: Mandar Maju.

[6] Irawaty, "Extradition agreement between Indonesia and Singapore," Indones. J. Int. Law, vol. 2, no. 4, pp. 830-841, 2005.

[7] J. Ginting, "Roles of the Mutual Legal Assistance and Extradition Agreements in the Asset Recovery in Indonesia." p. 575, 2012.

[8] S. Hartono, Pembinaan Hukum Nasional dalam Suasana Globalisasi Masyarakat Dunia. Bandung: Fakultas Hukum Universitas Padjajaran.

[9] I. W. Parthiana, Hukum Pidana Internasional dan Ekstradisi. Bandung: Yrama Widya, 2003.

[10] Erwin Hermawan, "Faktor Penyebab Kegagalan Ratifikasi Defence Cooperation Agreement (DCA) Indonesia dan Singapura," Universitas Indonesia, 2010.

[11] S. Syarifuddin, "Relevansi Undang-Undang No. 1 Tahun 1979 Tentang Ekstradisi Dengan Perkembangan Hukum Ekstradisi Internasional (Studi Kasus : Perjanjian Ekstradisi IndonesiaSingapura)," J. Komun. Huk., vol. 2, no. 1, pp. 94-113, 2016, doi: 10.23887/jkh.v2i1.7284.

[12] D. WARYENTI, "Ekstradisi Dan Beberapa Permasalahannya," FIAT JUSTISIAJurnal Ilmu Huk., vol. 5, no. 2, 2014, doi: 10.25041/fiatjustisia.v5no2.64

[13] R. Sanur, "Kebijakan pemerintah Indonesia meratifikasi perjanjian ekstradisi dengan Singapura," Universitas Riau, 2012.

[14] N. A. Sinaga and T. Zaluchu, "Peranan asas keseimbangan dalam mewujudkan tujuan perjanjian," J. Ilm. Huk. Dirgant., vol. 8, no. 1, pp. 38-56, 2017, doi: 10.35968/jh.v8i1.137.

[15] J. Milia, "Analisis hukum defense cooperation agreement antara Indonesia-Singapura tahun 20072017 melalui variabel keberhasilan diplomasi pertahanan," Universitas Pertahanan, 2017.

[16] A. S. Wicaksana, "Penundaan Indonesia dalam meratifikasi perjanjian ekstradisi dengan Singpaura tahun 2007-2014 (Studi kasus: Korupsi BLBI)," J. Int. Relations, vol. 2, no. 4, pp. 261-269, 2016.

[17] P. N. Utami, "Dampak hukum pengesahan persetujuan antara Republik Indonesia dan Republik Islam Iran tentang ekstradisi," J. Legis. Indones., vol. 15, no. 4, pp. 355-368, 2018. 